\title{
31 温湿度モニタの使用経験
}

飯島光雄, 安見 衛, 田代洋行, 藤井正実, 古垣達也（北里大病院ME七ンター部）, 渡辺 敏 (北里大医療衛生学部)

呼吸管理をする上で乾燥した吸入ガスを投与すると， 喀桨の粘度の増加とともに，繊毛上敢細胞の障害や緎 毛運動障害が起こり, 喀痰や気管内異物の喀出が困難 になることがある. 特に，人工呼吸器により管理され ている場合は，気管チューブにより上気道を通過する ためにここでの加温加湿ができなく，無気肺や肺炎な どの合併症を起こしやすくなる，そのため，人士呼叫 器には, 一般的に加温加湿器が不可久となっている.
しかしながら，速甽な加温加湿を行らためには，呼吸 回路の患者側で温度を測起する必要があり，温度表示 のない加温加湿器や回路では管理が煩雑になりやすい. 今回, 人工呼吸器の呼吸回路内の温度および湿度を 簡监にモニタできる，スカイネット社製モイスコープ を使朋与る機会を得たので，その性能と有用性につい て報告与る。

\section{2 熱変換を利用した除細動器簡易チェッカの研究}

小野哲章 (神奈川県立衛生短大衛生技術科)，加納 隆（三井記念病院MEサービス部）

病院に和けるME機器の保守管理は機器を使った医 療の信頼性・安全性を確保する上で重要である.

機器の信頼性・安全性を確保するには，製造側で規 格にあった優秀な機器を設計・製造することが先ず第 一であるが，使用側での適切な使朋と適切な保守管理 が, 機器自身の信頼性や安全性を十分に引き出方上, 重要であることも論をまたない。

特に, 機器の日常的, 定期的な点検は, 不具合の早 期発見と他の患者への事故の波及觉防ぐ意味からも重 要でする.

我々は，病院で院内の臨休工学技士等が使える, 比 較的容易に製作できかつ廉俩なME機器チェッカを試 作し，奏際の現場での活用方法等を報告してきた。

除細動器チェッカについても, ピーク電圧簡易チェ ッカ，エネルギー計算型チェッカ等を発表してきたが，
今回は，通電エネルギーを熱変換することによって， さらに容易に出力ェネルギーをチェックできる簡易子 エッカを設計・試作したので報告する.

試作したチェッカは, 円筒形の容器に入れた食塩水 の両端に電極を付けたものを $50 \Omega$ 負荷とし，これに 通電し，その食塩水の温度上昇をサーミスタ等で測定 するといら簡単な原理と構造を有している。

通電エネルギー $\mathrm{E}(\mathrm{J})$ と $\mathrm{m}(\mathrm{g})$ の水の温度上昇 $\triangle \mathrm{T}\left({ }^{\circ} \mathrm{C}\right)$ との間には,

$$
\mathrm{E}=4.2 \mathrm{~m} \triangle \mathrm{T}
$$

の関係があるので, 温度上昇を測れば容易に出力ェネ ルギーが求められるわけである。

本原理に基ついて, 熱変換型除細動器簡易チェッカ を試作し，その精度等を従来チェッカと比較検討し， その利点と問題点を明らかにする. 